\title{
Intravenous Immunoglobulin Replacement Therapy in Children with Primary Immunodeficiency Diseases: A Nurse's Guide
}

1 Ana Marija Hošnjak

1 Snježana Čukljek

1 Sanja Ledinski Fičko

1 Martina Smrekar

2 Nikolina Veriga

3 Danijela Vrankić

4 Štefanija Kolačko

${ }^{1}$ University of Applied Health Sciences, Department of Nursing, Zagreb, Croatia

2 Department of Anesthesiology, Reanimatology and Intensive Care, "Dr. Tomislav Bardek" General Hospital, Koprivnica, Croatia

${ }^{3}$ Srebrnjak Children's Hospital, Zagreb, Croatia

${ }^{4}$ Clinical Hospital "Sveti Duh", Zagreb, Croatia

Article received: 01.09.2018

Article accepted: 24.11 .2018

Author for correspondence:

Ana Marija Hošnjak

University of Applied Health Sciences

Mlinarska cesta 38, 10000 Zagreb

Phone: + 385914595714

E-mail: anamarija.hosnjak@zvu.hr

DOI: $10.24141 / 2 / 2 / 2 / 7$

Keywords: primary immunodeficiency, substitution therapy, nurse

\section{Abstract}

Primary immunodeficiency diseases are chronic disorders which are characterized by increased sensitivity of the organism to infections because one or more parts of the body's immune system is missing. Immunoglobulins are normal components of the human body with the main role in the immune defense. Children with primary immunodeficiency have little or no antibodies and lifelong routine replacement therapy is the only effective treatment which represents the gold standard in treatment. The purpose of this therapy is to prevent acute infections and reduce complications resulting from infection. A nurse equipped with knowledge and competences is an indispensable link in the safe and quality administration of immunotherapy and in providing immediate psychological support to the child and the entire family. Nurses administer $90 \%$ of all intravenous immunoglobulin therapy transfusions according to the provisions of the physician.

The paper presents findings of a research study into nurse's perceptions about the Immunoglobulin replacement therapy. This paper represents nursing guidelines before, during and after administering intravenous immunoglobulin in children with primary immunodeficiency disease. 


\section{Introduction}

Primary or congenital immunodeficiencies (PID) are caused by genetic defects which in turn interrupt the maturation and functioning of various components of the immune system. Immunodeficiency may be independent or linked to a syndrome. The diseases are usually already present in infancy and childhood and are manifested as common (recurrent) or unusual infections. They are characterized by a lack of antibodies (agammaglobulinemia), antibody deficiencies (hypoglobulinemia) and a lack of specific subclasses of immunoglobulins (normoglobulinemia). These children are immunocompromised against all opportunistic infections and are also prone to allergies and autoimmune diseases.

More than 250 PID entities have been defined to date, with the number rapidly evolving $(1,2)$.

This paper will review certain anecdotal evidence for indications and administration of intravenous immunoglobulin (IVIG). In additional to the review in the table further on, the adverse effects of IVIG therapy and interventions by nursing personnel is addressed.

The goal of IVIG infusion in nursing practice should be to deliver therapy safely and effectively. A nursing policy should be in place for treatment and management of all adverse reactions.

\section{Immunodeficiency}

Immunodeficiencies should be suspected as the cause of recurrent infections when atypical signs and symptoms occur (recurrent otitis media after antibiotic treatment, chronic recurrent rhinosinusitis, persistent pneumonia after adequate therapy with antibiotics), when usually accompanied by complications and resistance to treatment, or in the case of infections caused by unusual microorganisms.

Infections of the upper and lower respiratory tract are the most commonly reported symptoms (sinusitis, bronchitis, pneumonia), as well as gastroenteritis, but serious bacterial infections such as meningitis may also occur. Immunodeficiency should be suspected in infants or small children with chronic diarrhea and growth delay, especially when diarrhea is caused by unusual viruses such as, for example, adenoviruses (3). Frequent use of antibiotics may at times mask many of the common symptoms and signs of infection (4). Due to the weakness of the immune system, changes in skin and mucous membranes are commonly reported (e.g., eczema, warts, abscesses, pyoderma, oral and esophageal ulceration, and periodontitis). After thoroughly reviewing a patient's medical history, undergoing a physical examination and taking blood tests, a final confirmation of diagnosis is possible based on the results of immunological and genetic tests.

Given that recurrent infections are the main problem, several specific types of therapy are available for children with a primary immunodeficiency disease where such therapies strengthen immunity. One of these is replacement therapy for missing components of the immune system. Replacement therapy can also include IV immunoglobulin and hematopoietic stem cell transplantation.

\section{IVIG therapy}

Intravenous immunoglobulin therapy is a human antibody solution which has been used as a medical treatment for decades. However, its use has increased over the last few years due to good responses in the body when treating various diseases. As was the case with prophylaxis for measles, hepatitis and polio, the concentration of human IVIG began to be used as early as World War II. Most often, the therapy was administered only subcutaneously and intramuscularly (5).

Immunoglobulin preparations are extracted from the serum of 1,000-60,000 voluntary healthy donors, a combination of several thousand donors depending on the manufacturer $(6,7)$ who go through screening for possible infections such as hepatitis B, C and HIV. The WHO has published minimum standards for manufacturing IVIG preparations (7):

- IVIG should be extracted from a pool of a least 1000 individual donors

- IVIG should contain as little IgA as possible

- IVIG should be free from preservatives or stabilizers that might accumulate in vivo

The preparations contain highly purified (> $95 \%$ ) polyvalent IgG (8).

Immunoglobulin $\mathrm{G}$ is prepared from the fractionation of a large amount of normal human plasma and contains a wide spectrum of antibodies (9). 
It may take several infusions to develop a tolerable specific IVIG regimen for each patient. While all Ig products provide necessary antibody replacement, each has subtle differences and are thus not interchangeable because switching from one brand to another is one of most common causes of side effects (10).

\section{Adverse reactions}

Although all donors are required to undergo screening, there is possibility that late complications may occur, such as more severe infections, after taking blood before seroconversion (11).

Like any other form of treatment, the use of immunoglobulins presumes a certain risk of adverse events and side effects. The side effects of IVIG treatment relate mainly to the dosage and rate of administration. Reactions are categorized as early and late reactions based on reaction times, while the criterion for the reaction onset mechanism leads to the twofold categorization, specifically immune-related and non-immunological. Early side effects occur within 30-60 minutes after commencing administration $(12,13)$, while Richter (2005) notes that hepatitis, HIV, meningoencephalitis are possible late reactions given that immunoglobulins are obtained from various volunteer blood donors $(11,14)$. Side effects may be mild, moderate or life-threatening depending on the clinical condition (Table 1).
Mild reactions include dizziness, headache and flashes of light in vision. Other symptoms such as fever, nausea, vomiting, joint pain and moderate back or hip pain may also occur $(15,16)$. Moderate reactions include strong headaches that do not stop after the administration of analgesics, rashes with or without itching, and the exacerbation or recurred appearance of mild reactions. The most common delayed systemic reaction is persistent headache (17).

Flu-like symptoms are the most frequent adverse effects (18). One retrospective study showed that 14 of $16(87.5 \%)$ patients developed flu-like symptoms during immunoglobulin administration (19).

As with other blood products, administration of immunoglobulins may lead to serious complications such as hemolytic anemia, anaphylactic reactions (13), renal insufficiency, aseptic meningitis $(11,20)$ and exacerbation of all moderate reactions. Fortunately, severe side effects are rare $(15,21)$. Recognizing and preventing late reactions in a timely manner requires placing the child under observation for at least 24 hours. Constant hydration and taking of fluids is necessary for maintaining normal renal function. All symptoms and signs of allergic reaction must be documented.

Some of the necessary nursing procedures are given in Table 2.

\begin{tabular}{|c|c|c|}
\hline $\begin{array}{c}\text { MILD } \\
\text { (most common, usually } \\
\text { immediate) }\end{array}$ & $\begin{array}{c}\text { MODERATE } \\
\text { (common, usually delayed) }\end{array}$ & $\begin{array}{c}\text { SEVERE } \\
\text { (rare) }\end{array}$ \\
\hline $\begin{array}{c}\text { Dizziness* } \\
\text { Light headache* } \\
\text { Flashes of light in vision* } \\
\text { Fever* }^{\star} \\
\text { Nausea* }^{*} \\
\text { Vomiting* }^{*} \\
\text { Fatigue* }^{*}\end{array}$ & $\begin{array}{l}\text { Persistent headaches** } \\
\text { Rashes* } \\
\text { Transient hypotension* } \\
\text { Wheezing or chest pain* }\end{array}$ & $\begin{array}{c}\text { Hemolytic anemia**} \\
\text { Renal insufficiency**} \\
\text { Aseptic meningitis** } \\
\text { Anaphylactic reactions*: } \\
\text { Respiratory symptoms: Chest pain, } \\
\text { clenching in the throat, a sense of lacking } \\
\text { air, bronchospasm, saturation below 94\%, } \\
\text { rhinitis, dry cough, angioedema, harsh } \\
\text { voice, stridor } \\
\text { Abdominal symptoms: Abdominal pain, } \\
\text { cramps, diarrhea, nausea, vomiting } \\
\text { Circulatory: Hypotension, tachycardia, pale } \\
\text { and damp skin } \\
\text { Other: Itching, redness of the skin on the } \\
\text { neck, face and ears, watery eyes }\end{array}$ \\
\hline
\end{tabular}




\section{Table 2. Nursing interventions in case of unwanted reactions $(\mathbf{1 8 , 1 9 , 2 1 - 2 4 )}$}
UNWANTED REACTIONS
CAUSES
NURSING INTERVENTIONS
First infusion
Infusion rate may be too fast
Solution is not at room
temperature
MILD REACTION
Longer interval from prior infusion
Switch to a new product
Infusion rate may be too fast
Solution is not at room temperature
MODERATE REACTION
Inflammatory response to specific product
No pre-infusion or post- infusion hydration
SEVERE
Intolerance to product
High-dose IVIG therapy
Slow down the rate of administration or stop infusion for 15-30 minutes
If necessary, apply analgesic therapy
Assess pain on the pain scale
If headaches persist after 30 minutes, stop the infusion permanently
Slow down the rate of administration or stop the infusion for 15-30 minutes
If the nausea does not stop after 30 minutes, stop the infusion
Administer antiemetics if necessary Administer antihistamines and NSAIDs if necessary
The infusion should be stopped immediately.
In case of anaphylactic reactions administer adrenaline according to a clearly defined protocol In line with ERC guidelines, adrenaline must be administered intramuscularly in the anteromedial part of the upper leg as it maximizes absorption. Use of intravenous adrenaline should be performed only by physicians who are trained in administering vasopressors.
Oxygenation and IV fluid replacement Continuous patient monitoring is important

Depending on the indication, doses are determined according to the child's body weight and the laboratory findings pertaining to immunoglobulin. Therapy is repeated at regular intervals every 3 to 4 weeks (17), and it takes 3 to 6 months to achieve balance after the beginning of therapy.

The most common side effects are expected during the first administration of intravenous immunoglobulins $(21,22)$. The rate of infusion is determined by $\mathrm{ml} / \mathrm{kg}$ per hour. Infusion rates are usually started at $0.01-0.02 \mathrm{ml} / \mathrm{kg} / \mathrm{min}$ and increased up to $0.1 \mathrm{ml} / \mathrm{kg} /$ $\min (23)$.

\section{Nursing interventions during first IVIG administration}

Intravenous immunoglobulins are administered to children under hospital conditions in a strictly controlled environment, respecting all the rules for asepsis, and based on the physician's written order. Nurses administer the majority of immunoglobulin, in $90 \%$ of the cases (18). Prior to each IVIG administration, the nurse must be familiar with the specif- ics of the medicine and administration protocol and evaluate the existence and passage of the venous pathway, as well as the condition (size, elasticity, position) of the child's veins. IVIG are administered intravenously via an approved intravenous infusion pump. The American Academy of Allergy, Asthma and Immunology (AAAAl) strongly discourages the use of permanent indwelling ports or central venous lines in antibody deficient patients due to the risk of systemic infection (sepsis) and thrombotic events (25).

If IVIG is stored in a refrigerator, it needs to be warmed to room temperature (8) for at least 30 minutes before administration in order to minimize adverse effects. It must never be heated up in a microwave or in any other way as the protein may become denatured (8). Importantly, vigorous mixing is prohibited. All products should be inspected for the presence of particulates before pooling, and products with broken seals should not be used.

Education and moral support for the child and parents is very important. After a detailed medical history, physical examination and measurements 
of vital functions, the child is placed in a bed on a ward equipped with a central oxygen supply. Given that administration, depending on the dose, lasts for several hours, the child should be pleasantly accommodated and wear comfortable clothing prior to commencing the treatment. Premedication is most often not necessary (8) but is usually given if there has been a recent adverse reaction (14).

Before using IVIG, it is necessary to check the correctness of the drug packaging, the name and expiration date, manner of administering and the concentration based on the instructions and compare them with the physician's written order. If the child is to receive a number of bottles, the starting time for administration and sequential position of the dose in the overall order of doses should be written on each bottle. To maintain records on the temperature list, the name and lot number of the drug should be documented, and the empty vials are to be kept for 24 hours after administering.

When the drugs are administered, emergency equipment including adrenalin (1:1000) must be readily available for life support purposes, and in case of an anaphylactic reaction (26).

Visual monitoring and baseline vital function monitoring is necessary during the first 30-60 minutes from commencing administration because most of the early side effects occur in that period. Subsequently, vital signs are measured every 60 minutes and this is obligatory before each new dose. All parameters in children should be constantly monitored and a skin examination for rash and urticaria should be performed periodically, as well as other symptoms and signs that may indicate unwanted reactions. Every change in normal vital signs should be recorded. An adverse reaction to administered immunoglobulin may also be related to infusion rate, and it is also important to comply with speed-related guidelines. A nurse records the intake and the amount of fluid, while encouraging the child to take as much fluid as possible to prevent renal complications $(8,27)$.

\section{Nursing interventions during recurrent infusion}

Infusion of immunoglobulins is repeated at regular intervals every 3-4 weeks (8). During re-hospitalization, information should also be collected on previous use, possible complications (fatigue, headaches, nausea) and dosage toleration, including infection data during the three weeks following the last administration. Importantly, a child should be continually monitored if the last dose was administered more than 6 weeks ago (11), and if the infusion is administered from a new producer or if a higher dose is prescribed. For children, the best practice is not to change products once a particular brand has been commenced (14).

\section{Nursing interventions after completing therapy}

Physicians most frequently prescribe $0.9 \% \mathrm{NaCl}$ infusion to flushthe infusion line after the administration of immunoglobulin. If at the site of the intravenous cannula there is no redness, edema and other inflammation signs, the cannula can be left until completing the observation. Conversely, the nurse must remove the cannula and treat the inflamed IV site according to the protocol provided by the institution. In this case, the cannula is to be placed in another position, preferably on the opposite extremity. The exact time of terminating infusion is noted in patient documentation along with all vital baseline parameters and description of the child's condition.

After the infusion administration, nurse must provide patient/family education before discharge, regarding symptom management and appropriate actions for symptom severity. It is also necessary to inform the patient about the next arrival date, respecting the protocol of the drug administration.

\section{Psychological support for families}

In comparison with healthy children and adults, patients with PID experience measurably lower general health along with higher hospitalization rates and restrictions to physical, school, and social activities (28).

When a child is diagnosed with PID, often each member of the family has many questions. The whole family must come to terms with the illness and perhaps make major changes in schedules and priorities. Parents are often faced with many challenges, difficulties and decisions that other parents will never have to face.

One of the most important things for the whole family is to provide accurate age-appropriate information and explain everything about the diagnosis, therapy and solutions. A child's understanding of their PID 
depends on their cognitive development. Speaking with a child contributes to a sense of security and establishes trust between the nurse and child.

Some of the emotions that parents encounter are anger, guilt, embarrassment, sadness, loneliness, fear and confusion. Other feelings such as worry, stress and problems with sleep or appetite, a sense of loss and even a sense of relief are common.

Nurses must inform patients about the organizations that are raising the awareness of PID and offer support to individuals and families. Constant education of family and providing support are two of the most important roles due to the constant presence of fear and anxiety. Counselling sessions and mutual support groups are often the most appropriate forms of help where formal and informal caregivers are assisted in managing stress.

\section{Conclusion}

Primary immunodeficiency is not a rare occurrence; however, the real incidence and prevalence remains unknown until new screening tests for neonates are introduced. Today, frequent and recurrent infections are the usual signs of suspecting PID, and subsequently only tests designed for the final diagnosis. Occasionally, suspicions concerning the onset of the disease may take place earlier if a positive family history exists. An early diagnosis leads to timely treatment, disease prevention and better quality of life. To prevent frequent opportunistic infections, children with primary immunodeficiency diagnosis receive infusions of immunoglobulins at regular intervals in controlled conditions in a hospital environment, where nurses administer $90 \%$ of all IVIG transfusions in line with the physician's order. It is of utmost importance that nurses are educated about the type of immunoglobulin, the manner and rates of administration, possible complications and side effects, and that they are trained for timely response in such instances. Treating with immunoglobulin preparations is a demanding process in which all participants have an important role, starting with blood donors whose blood is processed in specialized transfusion facilities all the way up the chain to the child as the lifelong end user.

\section{References}

1. Struja T, Kutz A, Fischli S, MeierC, Mueller B, Recher M, Schuetz P. Is Graves' disease a primary immunodeficiency? New immunological perspectives on an endocrine disease. BMC Med. 2017;15:174.

2. Rider NL, Kutac C, Hajjar J, Scalchunes C, O. Seeborg F, Boyle M, Orange JS. Health-Related Quality of Life in Adult Patients with Common Variable Immunodeficiency Disorders and Impact of Treatment. J of Clin Immunol. 2017;37(5):461-475.

3. de Vries $E$, Driessen G. Educational paper: primary immunodeficiencies in children: a diagnostic challenge. Eur J Pediatr. 2011;170(2):169-177.

4. Khalilzadeh S, Boloorsaz MR, Baghaie N, Sadeghi MMR, Hassanzad M, Velayati AA. Primary Immunodeficiency in Children: Report of Seven Years Study. J Resp Dis Thorac Surg Intens Care Tuberc. 2011;10(2):38-43.

5. Kirmse J. The nurse's role in administration of intravenous immunoglobulin therapy. Home Healthcare Nurs. 2009;27(2):104-111.

6. Zago Novaretti MC, Dinardo CL. Immunoglobulin: production, mechanisms of action and formulations. Rev Bras Hematol Hemoter. 2011;33(5):377-382.

7. Zandman-Goddard G, Shoenfeld Y. Intravenous immunoglobulin-customized therapy. In: Autoimmunity From Bench to Bedside. Bogota (Colombia): El Rosario University Press; 2013.

8. Silvergleid AJ, Ballow M. In: Schrier S, Steihm R. (Ed.) Overview of intravenous immune globulin (IVIG) therapy. Up to date, 2017. Available from: https://www. uptodate.com/contents/intravenous-immune-globulin-adverse-effects Accessed: 23.01.2018.

9. Aghaie A, Pourfatollah AA, Bathaie SZ, Moazzeni SM, Pour H. Khorsand Mohammad, Banazadeh S. Preparation, purification and virus inactivation of intravenous immunoglobulin from human plasma.Human Antibodies. 2010;19(1):1-6.

10. Immune deficiency foundation IDF. About Primary Immunodeficiencies. Available from: https://primaryimmune.org/ about-primary-immunodeficiencies Accessed: 23.01.2018.

11. Richter D. Terapijska primjena polivalentnog humanog imunoglobulina u dječjoj dobi. Pediatr Croat. 2005;49:162-168. Croatian.

12. Immune deficiency foundation IDF. Primary immunodeficiency diseases in America: the third national survey of patients. 2007. Available from: https:// primaryimmune.org/wp-content/uploads/2011/04/ Primary-Immunodeficiency-Diseases-in-America2007The-Third-National-Survey-of-Patients.pdf Accessed: 23.01.2018.

13. Immune deficiency foundation. IDF guide for nurses on immune globulin therapy for primary immunodefi- 
ciency diseases. 2012. Available from: http://cipo.ca/ Nurses_Guide.pdf Accessed: 23.01.2018.

14. Malcolmson C, Xu-Bayford J, Worth A. Immunoglobulin infusions: intravenous and subcutaneous. Great Ormond Street Hospital for Children. Available from: http://www.gosh.nhs.uk/health-professionals/clinical-guidelines/immunoglobulin-infusions-intravenous-and-subcutaneous Accessed: 23.01.2018.

15. Orange $\mathrm{JH}$, Hossny JS. Use of intravenous immunoglobulin in human disease: A review of evidence by members of the Primary immunodeficiency committee of the American academy of allergy, asthma, and immunology. J Allergy Clin Immunol. 2006;117(4),525.

16. Younger MEM, Aro L, Blouin W, Duff C, Epland KB, Murphy $E$, et al. Nursing Guidelines for Administration of Immunoglobulin Replacement Therapy. Journal of Infusion Nursing. 2013;36(1),58-68.

17. Steihm ER. Adverse effects of Human Immunoglobulin Therapy. Transf Med Rev.2013;27:171-178.

18. Guo Y, Tian X, Wang X, Xiao Z. Adverse Effects of Immunoglobulin Therapy. Front Immunol. 2018;9:1299.

19. Seidling V, Hoffmann JH, Enk AH, Hadaschik EN. Analysis of high-dose intravenous immunoglobulin therapy in 16 patients with refractory autoimmune blistering skin disease: high efficacy and no serious adverse events. Acta Derm Venereol. 2013;93(3):346-9.
20. Cowden J, Parker SK. Intravenous immunoglobulin. Pediatr Infect Dis J. 2006;25(7),641-642.

21. Silvergleid AJ, Berger M, In Stiehm ER. (Ed.). Intravenous immune globulin: Adverse effects. 2011; Up to date. Available from: https://www.uptodate.com/contents/intravenous-immune-globulin-adverse-effects Accessed: 23.01.2018.

22. Finkel $A G$, Howard JF, Mann D. Successful treatment of headache related to intravenous immunoglobulin with antimigraine medications. Headache. 1998;38:317-321.

23. Prasad AN, Chaudhary S. Intravenous immunoglobulin in pediatrics: A review. Med J Armed India. 2014;70(3):277-28.

24. Simons FER, Ardusso LRF, Bilò MB, El-Gamal YM, Ledford DK, Ring J, et al. World allergy organizations anaphylaxis guidelines: Summary. J Allergy Clin Immunol. 2011;127(3):587-93.

25. Bonilla FA, KhanDA, Ballas ZK, etal. Practice parameter for the diagnosis and management of primary immunodeficiency.] Allergy Clin Immunol. 2015;136(5):1186-1205.

26. Broyles BE, Reiss BS, Evans ME. Pharmacological Aspects of Nursing Care. 7th Edition. Clifton Park, NY: Thomson Delmar Learning; 2007.

27. Pritchard J, Hughes RAC. Intravenous ImmunoglobulinHow to use it. Pract Neuro. 2001;1:93-97.

28. Jiang F, Torgerson TR, Ayars AG. Health related quality of life in patients with primary immunodeficiency disease. Allergy Asthma Clin Immunol. 2015;11:27. 


\section{NADOMJESNA TERAPIJA INTRAVENOZNIM IMUNOGLOBULINIMA KOD DJECE OBOLJELE OD PRIMARNE IMUNODEFICIJENCIJE: SESTRINSKE SMJERNICE}

\section{Sažetak}

Primarne imunodeficijencije stanja su koja odlikuje povećana osjetljivost organizma na infekcije zbog nedostataka jedne ili više komponenti imunološkog sustava. Imunoglobulini su normalni sastavni dijelovi ljudskog tijela s glavnom ulogom u imunološkoj obrani. Djeca koja boluju od primarne imunodeficijencije imaju ih malo ili ih uopće nemaju te kod njih cjeloživotna nadomjesna terapija imunoglobulina (IgG) predstavlja jedini učinkovit tretman kao zlatni standard u liječenju primarnih imunodeficijencija. Svrha je takve terapije prevencija akutnih infekcija te smanjenje komplikacija nastalih kao posljedica infekcije. Medicinska sestra sa svojim znanjem i kompetencijama neizostavna je spona u sigurnoj i kvalitetnoj primjeni imunoterapije, u pružanju neposredne psihičke potpore djetetu i cijeloj obitelji te je upravo ona primjenjuje u $90 \%$ slučajeva prema pisanoj odredbi liječnika.

Pregledom literature prikazane su spoznaje o percepciji medicinskih sestara u vezi s terapijom imunoglobulinima. Ovaj rad predstavlja smjernice medicinskim sestrama za skrb prije, tijekom i nakon primjene intravenskih imunoglobulina kod djece s primarnom bolešću imunodeficijencije.
Ključne riječi: primarne imunodeficijencije, nadomjesna terapija, medicinska sestra 